\title{
The Interactive Teaching Mode in High-School Class
}

\author{
Liu Liwen \\ NanChang Institute of Science \& Technology
}

\begin{abstract}
For a long time, English teaching in China's high schools has achieved lots of achievements on language knowledge; however, due to the college entrance examinations, traditional English teaching in China is oriented by examinations without much attention to cultivating students' practical application ability and initiative. Therefore, it is urgent to form a class teaching mode with students as the center so as to truly change the traditional teaching method and cultivate students' practical application ability of English. Thus, the study on interactive teaching mode in high-school class is not to elaborate English teaching theories comprehensively but to solve current practical problems we are faced with in high-school English teaching. In the paper, study and analysis are conducted on the interaction and factors in high-school teaching from the perspective of English teaching and basic interactive theories. Addressing the problems, study on the design of interactive teaching mode between teacher and students has been made.
\end{abstract}

Keywords-English;l teacher and students; interaction; teaching strategies

\section{I.INTRODUCTION}

As one of the most major courses, English has received more and more attention for its importance. Many people consider that the level of people's English can directly affect the process of reform and opening up as well as modernization. That is, mother language, English and computer language are three implementation languages that modern people should master. In the past 30 years since the reform and opening up, China has made great progress in English teaching, during which extraordinary achievements have been made from national policies of foreign language to curriculum construction and to theoretical study and practice of teaching methods. However, in general, theoretical studies on English teaching are still on a low level, and even many teachers who work in the front line are strange with theories. Besides, due to various restrictions, English teachers have less opportunities to receive further study and academic exchange, which greatly restricts English teacher's vision and the development of English teaching practice as well as quality of English teaching.

This paper mainly studies the application efficiency of interactive teaching mode in high-school English class with motivation, linkage and activeness. The main purpose is to verify if this teaching mode is effective in practical teaching in terms of improving students' participation in class interaction, development of students' initiative of study as well as raising students' learning interest and result. Meanwhile, through practice, some problems and inefficiencies of this mode has been discovered, which needs to be further perfected.

\section{II.THE SIGNIFICANCE OF INTERACTION BETWEEN}

TEACHER AND STUDENTS IN HIGH-SCHOOL CLASS

School is just as a cell of society, the main position of implementing education. Class teaching is the basic means of education as well as a large stage connects people to the society. The social ideology, moral standards as well as values can all be reflected in school and class, and they will finally affect students during interpersonal relationship. The significance of class interaction is mainly reflected in the following aspects.

\section{A. It is good for the formation of cooperation and competition mechanism}

Cooperation and competition are the main motivations for students during teaching process. Cooperation is the base of competition, through which students can better understand each other, learn from 
each other and make complements for each other. Competition can stimulate students to make further progress and achievement. The class interaction can rightly provide such an opportunity for students' cooperation and competition, and meanwhile it can help to cultivate students' awareness of cooperation and competition as well as moral qualities.

\section{B. It is helpful for forming sound interpersonal relationship and improving teaching efficiency.}

According to the study of educational sociology, information communication in class teaching system is not only a bilateral communication process between teachers and students; while it is conducted under the influence of various information factors from inside and outside circumstance. The interpersonal relationship in class can not only affect teaching efficiency, but it can also affect students' growth. In a class with interaction, teacher and students are considered equal to each other, and they can make interactive effect and improvement both on knowledge exchanges and emotional communication.

\section{It is good to the timely feedback of teaching}

information and sharing of teaching resources.

In a unidimensional class, class teaching activity is actually an enclosed class, in which the main sources for students' acquisition of information are books and teachers. In fact, both the teacher and students in class teaching can become information sources since their behaviors can affect others or be affected by others. In this process, teaching information can be reflected timely with sharing of teaching resources.

\section{III.PROBLEMS EXISTING IN THE INTERACTION BETWEEN THE TEACHER AND STUDENTS IN HIGH-SCHOOL ENGLISH CLASS}

The unidimensional and simple teaching activities in high-school English class are caused by many factors. One of the main reasons is the teaching mode is too old. Therefore, it is necessary for us to explore a new teaching mode with multi-dimensional and multi-interactive ways between the teacher and students in high-school students.

\section{A. Teachers have serious monopoly position}

Through interview with high-school English teachers, I found that some teachers prefer to interact with bold, active and confident students with better performance strong oral ability so as to control the class and make the teaching smoothly. These students are easy to be interacted with; while students with poor performance may be difficult to be interacted with regardless of quality and speed.

B. The interaction between the teacher and students is not deep

During the interaction between teachers and students in high-school English class, teachers only choose to interact with individuals by some common but less impressive ways. Thus the interaction can't reflect difference, diversity and sense of depth.

\section{IV.COUNTERMEASURE TO IMPROVE INTERACTION} BETWEEN TEACHERS AND STUDENTS IN HIGH-SCHOOL

\section{ENGLISH CLASS}

\section{A. Define the teaching goals}

English in high-school class teaching is a subject which can most reflect the interactive features between students and teachers among all subjects. One important thing of class interaction is to define its purpose besides the implementation. In the traditional English class teaching, more importance has been given to the implementation of interaction instead of interaction itself as well as the result of interaction.

\section{B. Create situation for interaction}

The strategy of situation creation is a strategy which attracts students' attention and improves their learning activeness by using various situations similar to the teaching contents so as to form a sound interaction atmosphere at the beginning of the class. A class with suitable situation creation can easily attract students' interest and attention, and thus they can actively participate in class interaction.

\section{Improve the measures of interaction}

In the class interaction, students and teachers should be seen as equal and they should cooperate with each other equally. The teacher can't monopolize the class 
without interaction with students. In English teaching with interpersonal interaction as orientation, students' dominant role should be ensured so that students can have more initiative to participate in study to learn more knowledge.

\section{V.CONCLUSION}

By employing the interactive teaching mode in high-school English teaching, students' participation in class teaching has been promoted with higher initiative, and thus their learning results and learning interest have also been improved. Meanwhile, during the interaction, they can also have positive exchange of thoughts, enlightenment of inspiration, communication of emotions, exercise of will as well as education of personality. As a result, students can be developed in a comprehensive way. To my point of view, there are mainly several reasons for this effect as follows.

First, the interactive teaching mode in high-school English class creates more opportunities for students to participate in class teaching activities so as to raise the interaction participation rate. During the interaction, students can acquire more knowledge and better develop their abilities instead of listening to teacher silently as before.

Second, the interactive teaching mode in high-school English class has created more chances for students' initiative study since students and the teacher are assigned tasks together under this teaching mode so that students can truly feel each part of teaching activities instead of listening or watching passively.

\section{REFERENCES}

[1] Quirk R, Greenbaum S, Leech G, et al. A Comprehensive Grammar of the English Language[J]. Language, 1985 , 69(2):13-16.

[2] Miller, George A. "WordNet: a lexical database for English." Communications of the Acm 38.11(1995):39-41.

[3] Swales, John. "Genre Analysis: English in academic and research settings." Cambridge University Press (1990).

[4] Chomsky, Noam, and M. Halle. The sound pattern of English. MIT Press, 1991.

[5] Dan, Douglas, and K. M. Broussard. Longman grammar of spoken and written English. Longman, 1999:132-139.

[6] Marcus, Mitchell P., M. A. Marcinkiewicz, and B. Santorini. "Building a Large Annotated Corpus of English: The Penn Treebank." Computational Linguistics 19.2(1993):313-330

[7] Biber, D., Johansson, S., Leech, G., Conrad, S., Finegan, E., \& Hirst, G. (2002). The longman grammar of spoken and written english. Tesol Quarterly, 34(03), 132-139.

[8] Marcus, Mitchell P, B. Santorini, and M. A. Marcinkiewicz. "Building a laxge annotated corpus of English: The Penn Treebank." Computatzonal Linguistics 1993:313-330.

[9] MARCUS M. P, SANTORINI B, MARCINKIEWICZ M. A Building a large annotated corpus of english: the Penn Treebank = La construction d'un grand corpus annoté en anglais : le Penn Treebank $[\mathrm{J}]$. Computational linguistics - Association for Computational Linguistics, 1993.

[10] Summers, Della, and Longman (Firm). Longman dictionary of contemporary English. Longman, 2001.

[11] Quirk, and Randolph. A Grammar of Contemporary English Longman, 1972:119-128.

[12] Association, Japanese Gastric Cancer. "Japanese classification of gastric carcinoma: 3rd English edition." Gastric Cancer 14.2(2011):101-112. 